MORIN, VICTOR, L.L.D., président de la Société d'archéologie et de numismatique de Montréal, Les Ramezay et leur château. Édition du 250e anniversaire de la construction du Château de Ramezay, with an English version entitled: De Ramezay Family and Chateau, by John D. King, B.Sc, vice-president of the Antiquarian and Numismatic Society of Montreal. Montréal, 1955. $127 \mathrm{p}$.

\title{
Lionel Groulx
}

Volume 9, numéro 2, septembre 1955

URI : https://id.erudit.org/iderudit/301718ar

DOI : https://doi.org/10.7202/301718ar

Aller au sommaire du numéro

\section{Éditeur(s)}

Institut d'histoire de l'Amérique française

ISSN

0035-2357 (imprimé)

1492-1383 (numérique)

Découvrir la revue

Citer ce compte rendu

Groulx, L. (1955). Compte rendu de [MORIN, VICTOR, L.L.D., président de la Société d'archéologie et de numismatique de Montréal, Les Ramezay et leur château. Édition du 250e anniversaire de la construction du Château de Ramezay, with an English version entitled: De Ramezay Family and Chateau, by John D. King, B.Sc, vice-president of the Antiquarian and Numismatic Society of Montreal. Montréal, 1955. 127 p.] Revue d'histoire de l'Amérique française, 9(2), 302-303. https://doi.org/10.7202/301718ar d'utilisation que vous pouvez consulter en ligne. 
Morin, Victor, L.L.D., président de la Société d'archéologie et de numismatique de Montréal, Les Ramezay et leur château. Edition du 250e anniversaire de la construction du Château de Ramezay, with an English version entitled: De Ramezay Family and Chateau, by John D. King, B.Sc., vice-president of the Antiquarian and Numismatic Society of Montreal. Montréal, 1955. 127 pages.

Ce volume, nous avertit l'auteur en sa préface, «a pour but de faire mieux connaître... la vie tourmentée d'une famille 
française » et aussi l'histoire du «noble édifice » construit par ces Ramezay, l'une des «quatre seules constructions du régime français qui sont encore intactes à Montréal ». On lira donc en cette centaine de pages, une courte biographie de la famille Ramezay, et surtout l'histoire aventureuse du Château. L'histoire de la Famille Ramezay a permis à l'auteur de vivantes évocations du passé français: Montréal au XVIIe siècle, mariages de grands en 1721, costumes, fêtes de l'époque. L'histoire du château, ou ce que M. Morin intitule à dessein le «roman du Château », démontre ce qu'il en coûte, au milieu d'un peuple qui a perdu le sens de son histoire, pour sauver de la démolition les plus authentiques monuments de son passé, qui en sont à la fois les plus valables. Grâce à la Société d'archéologie, et grâce, on peut le dire, à la ténacité de son président actuel, le Château Ramezay, sauvé du pic des démolisseurs et du mépris d'édiles ignares, sera devenu le «temple du souvenir », et, par sa galerie des portraits, sa salle d'archéologie, sa salle historique, sa salle indienne, son cabinet de numismatique, etc., l'un des musées les plus intéressants de Montréal.

Lionel Groulx, ptre 